Article

\title{
Stories that Change Our World? Narratives of the Sustainable Economy
}

\author{
Anna-Lena Guske ${ }^{1, *}$, Klaus Jacob ${ }^{1}$, Martin Hirschnitz-Garbers ${ }^{2}{ }^{\mathbb{D}}$, Jan Peuckert ${ }^{3}{ }^{\mathbb{D}}$, \\ Stefan Schridde ${ }^{4}$, Sven Stinner ${ }^{5}$, Franziska Wolff ${ }^{6}$, Dominik Zahrnt ${ }^{7}$ and Florence Ziesemer ${ }^{8}$ (i) \\ 1 Environmental Policy Research Centre, Freie Universität Berlin, 14195 Berlin, Germany; \\ klaus.jacob@fu-berlin.de \\ 2 Ecologic Institute, 10717 Berlin, Germany; martin.hirschnitz-garbers@ecologic.eu \\ 3 Institute for Ecological Economy Research (IÖW), 10785 Berlin, Germany; jan.peuckert@ioew.de \\ 4 MURKS? NEIN DANKE! e.V., 13088 Berlin, Germany; stefan@schridde.org \\ 5 ZIRIUS Center for Interdisciplinary Risk and Innovation Studies, University of Stuttgart, \\ 70174 Stuttgart, Germany; sven.stinner@sowi.uni-stuttgart.de \\ 6 Oeko-Institut, 10179 Berlin, Germany; f.wolff@oeko.de \\ 7 (r)evolutionary Ideas, 10437 Berlin, Germany; zahrnt@revolutionaere-ideen.de \\ 8 Chair for Business Administration/Marketing, University of Potsdam, 14482 Potsdam, Germany; \\ florence.ziesemer@uni-potsdam.de \\ * Correspondence: anna-lena.guske@fu-berlin.de
}

Received: 30 September 2019; Accepted: 25 October 2019; Published: 4 November 2019

\begin{abstract}
Narratives are shaping our understanding of the world. They convey values and norms and point to desirable future developments. In this way, they justify and legitimize political actions and social practices. Once a narrative has emerged and this world view is supported by broad societal groups, narratives can provide powerful momentum to trigger innovation and changes in the course of action. Narratives, however, are not necessarily based on evidence and precise categories, but can instead be vague and ambiguous in order to be acceptable and attractive to different actors. However, the more open and inclusive a narrative is, the less impact can be expected. We investigate whether there is a shared narrative in research for the sustainable economy and how this can be evaluated in terms of its potential societal impact. The paper carves out the visions for the future that have been underlying the research projects conducted within the German Federal Ministry of Education and Research (BMBF) funding programme "The Sustainable Economy". It then analyzes whether these visions are compatible with narratives dominating societal discourse on the sustainable economy, and concludes how the use of visions and narratives in research can contribute to fostering societal transformations.
\end{abstract}

Keywords: narratives; sustainable economy; societal impact of research; research communication

\section{Introduction: Telling Stories-The Power of Narratives and Their Role in Research}

\subsection{Narratives as a Tool to Shape Public Discourse}

A transformation towards a sustainable economy requires innovation in all parts of society. Technical, institutional, and social innovations have to be aligned with the broader societal goals for a sustainable economic system, which may have far-reaching consequences for society. Not only must production be rethought, but also consumer behaviour must change. New forms of production and cooperation between consumers and producers have to be established and new institutional setups are required to support these new patterns of consumption and production, in order to facilitate a 
sustainable economy [1]. For these innovations to be successful, it is critical that the general public accepts and applies such innovations, and embraces the changes resulting from their utilization [2].

In this regard, communication is an important aspect of creating and maintaining acceptance for innovation in general and sustainable innovations in particular. As Becker [3] has shown for digital transformation, a process of profound societal change needs a compelling narrative in order to align with broader societal values.

Narratives are a social construct that describe reality in a teleological way [3]. Hence, they link different frames or "schemata of interpretation" that enable individuals "to locate, perceive, identify, and label" occurrences within the world at large and their life space in particular [4] (p. 21). Narratives emerge when similar frames are linked to create storylines. These narratives point to different root causes of a problem, hold different actors accountable, and help to justify different courses of action. Frames and narratives are hereby supposed to "mobilize potential adherents and constituents to garner bystander support and to demobilize antagonists" [5] (p. 198), [6].

The relevance of narratives is widely accepted: Empirical studies on such linguistic constructs in policy analysis are now a well-established scientific field $[7,8]$. Narratives, however, are not necessarily based on evidence and precise definitions; ambiguity, vagueness, and normativity are key characteristics. There are potential trade-offs between the concreteness of narratives on the one hand, and their ability for mobilization and acting as a basis for consensus on the other hand. A narrative may be very vague and consequently find widespread support, but may not entail concrete guidance for action if it is too broad and covers too many options and potential pathways for action; while another narrative may point to concrete actors or problems but does not find support from a large number of actors, because it is too narrow and does not provide sufficient links to other ideas, images or visions [9].

Due to these characteristics of narratives, they cannot be constructed from a purely scientific process (or a small, distinct group in general). Rather, they are shaped by public discourse as sets of ideas, concepts, metaphors, discourses, or storylines about change and innovation [10]. In addition, because of their power to legitimize and mobilize, narratives are typically contested and compete for interpretive sovereignty. In this context, the scientific validity of a narrative is only one factor and not necessarily the most important one.

Narratives provide a relatable framework for groups of actors and shape our understanding of the world. Narratives transport values and norms and point to desirable future developments. Hence, we define narratives as a shared and consistent vision of the future, pointing out dysfunctionalities of the current system and illustrating pathways to achieve the desired future. They justify and legitimize political actions and social practices. Hence, they:

- facilitate communication about specific issues,

- provide instructions for action,

- can help to either preserve or change current value systems,

- provide reference points for societal actors,

- configure political alliances and actions, and

- create political positions and their strategic legitimacy $[7,8,11,12]$.

A simple example to illustrate these functions are the different narratives on innovation: Traditionally, the economic narrative describes innovation as a response to a shortcoming of prevailing technologies with regard to the needs of individuals. Innovation that effectively serves theses needs will contribute to market success and economic growth [3]. The narrative on innovation for a sustainable economy is different. In this context, innovations serve the needs of society by contributing to the preservation of social cohesion and the protection of natural resources. They may enhance wellbeing (instead of monetary values only) [13]. 


\subsection{Narratives in Science and Research}

As Becker [3] has shown, narratives are a crucial success factor for innovations. The framing of an innovation determines whether it can be accepted in society. Innovations are, by definition, unfamiliar and new to society. Narratives help to frame innovations and put them in a familiar context. This frame also determines whether an innovation has a positive or negative connotation and therefore influences its chances of being successful [2].

Hence, narratives influence science and innovation. Godin [14] has shown how societal narratives have influenced science policy and the funding priorities of research funders since 1945.

Moreover, researchers are increasingly expected to participate in public discourse and embed their research questions and results in societal discussion. They are thereby shaping and creating narratives, while at the same time existing narratives also influence science and research. Researchers have extensively studied the use and role of narratives in science communication and how researchers can heighten the impact of their research if they communicate their findings through compelling narratives [15-17].

However, we argue that narratives do not only play a role in the communication process of disseminating scientific findings, but that research projects also implicitly refer to or entail narratives inherently in their design. In this view, narratives shape the research process from early on, however researchers do not make these underlying narratives explicit.

Given the specific challenges with innovations for sustainability that aim at developing solutions for societal challenges [15], we would argue a reflection on the (often implicit) narratives is of particular relevance. Many research projects aim to contribute to the establishment of a sustainable economy by developing social and technical innovations that aim to change consumer behaviour, to establish transparency about the sustainability of products, and to make products more sustainable by using less or different materials, etc.

If we take a closer look at research projects within the context of socioecological research, we can observe that the underlying understanding of what a sustainable economy looks like differs profoundly between these research projects. We find competing narratives that envision different "sustainable economies" and the transformation paths to achieve them. Usually, these narratives share the goal of staying within the limits of the planetary boundaries $[18,19]$. However, visions of how this could be achieved point to very different pathways. For example, the green economy narrative envisions a transformation within the current economic system without changing its fundamental principle of economic growth. Structural and technological change are regarded as the main leverage. Other narratives are questioning this view, arguing that a transformation is only possible if we fundamentally rethink our economic structures, for instance by placing sufficiency at the center of economic change $[20,21]$.

Depending on the narrative of a sustainable economy that researchers have in mind when designing a research project, the aims of research (e.g. developing solutions for sufficient lifestyles vs. solutions for more efficiency) may differ and the communities that may take up the results change. Hence, the underlying narratives change the outcome of research projects and are therefore not only important in science communication at the end of the project cycle. Instead, by being transparent about underlying perceptions of the world from early on in the research project, researchers who aim at developing solutions for current societal challenges can increase their impact on society.

In the following section, we will answer the research questions:

(1) Which narratives are used in research projects and, in particular, which visions of a sustainable economy do they use to embed their results, and

(2) How do these stories relate to current societal discourse?

Firstly, developing innovations and demonstrating their contribution to the sustainable economy presupposes that researchers have a vision of the sustainable economy in mind. Nevertheless, visions often remain implicitly included in the design of the research. Secondly, we assume that researchers do 
not refer to the same narratives. Rather, they build on different narratives depending on the theoretical backgrounds and previous research experiences of the researchers involved.

We will focus on the visions underlying the narratives as opposed to other elements of narratives as visions can be found in all narratives [1]. A vision in this context describes a positive, and therefore desirable, future. In the discussion, we will consider how the visions for the future used in research link with broader societal discourse and with the currently dominant narratives in society in order to reach conclusions about the communicability of research results.

\section{Materials and Methods: Identifying Narratives of a Sustainable Economy}

To be able to answer the proposed research questions, we first needed to conduct an overview of the current narratives used in society. Secondly, we analyzed a sample of research projects to learn about the narratives used in the context of a sustainable economy. Lastly, we compared the outcomes of both analyses to reach a conclusion about which narratives are used in research and how they relate to the discourses currently dominant in society.

The first step in the process was a literature review, which we conducted in 2016 [13]. In this review of academic publications and strategy documents of the German government and other political actors, such as international organizations and non-governmental organizations (NGOs), we extracted the currently dominant societal narratives of a sustainable economy as a basis for the analysis. We analyzed the different concepts of a sustainable economy, examining which societal groups use them and how they differ with regard to (a) their analysis of the underlying problems leading to unsustainable behaviour, (b) their visions for a sustainable future, and (c) the pathways to achieving these visions.

Secondly, we carved out the underlying visions of a sample of research projects. We chose projects funded within the Socio-Ecological Research framework programme (SÖF) by BMBF (the German Federal Ministry for Education and Research). SÖF, in general, focuses on supporting the development of solutions for societal transformation processes guided by the principle of sustainable development. Research projects funded in this programme are generally transdisciplinary in nature and aim at developing practice-oriented results together with society, businesses and policy-makers. The funding scheme on the sustainable economy within this programme addresses the general question of how we can achieve a sustainable economy. As it is the explicit aim of the programme to provide not only new academic insights, but also practice-oriented recommendations, the projects refer (explicitly or implicitly) to narratives for the sustainable economy. At the same time, the projects cover a great variety of topics. These topics span from new approaches for sustainable nutrition, analyzing the sustainability potentials of the sharing economy, to developing innovative ideas for sustainable decorative plants or bioplastics. The projects not only cover many different economic aspects, but also use different methodological approaches, such as living labs or life-cycle-assessments [22]. As the projects cover a broad variety of topics and approaches, they constitute an interesting sample to identify and assess different narratives of the sustainable economy.

A review of project publications turned out to be insufficient for extracting narratives of a sustainable economy, as we found that most projects seemed to have a vision for the sustainable economy in mind, but that the underlying narratives were not explicit. Therefore, we decided to extract the narratives underlying the projects' conclusions and policy recommendations in a structured way. Our objective was to identify visions across different projects, to link the various elements and to eventually identify a vision for a sustainable economy. We invited the participants to bring forward not only scientific arguments, but to take a normative view on the economy and the innovations which they are working on.

As we were not only interested in the narratives used in single projects, but wanted to learn about common approaches, joint views, and diverging understandings of different projects, we opted for conducting a joint workshop with project representatives instead of separate interviews. In the workshop, we used a design-oriented, participatory method to visualize the project narratives in a 
structured yet creative way [23]. At the workshop (held in April 2018), we asked the participants to define the three main elements of narratives:

- the underlying problems inhibiting a sustainable economy,

- necessary next steps to solve the problem, and

- a vision for a sustainable economy.

These elements were depicted in a strategy map [23], which enabled the participants to isolate and define the elements of the narratives they used. In a second step, the participants then clustered the elements to identify common reasoning and storylines. In group-exercises, the participants visualized connecting points between the different elements and started to build coherent stories. Thirdly, by contrasting the elements, it was possible to identify both common factors and different views on the sustainable economy and to draw conclusions regarding which prevalent societal narratives are compatible.

In the last step, we compared the results from the literature review [13] to the narratives extracted from the projects. In order to answer the question of how these narratives relate to the prevailing societal narratives of the sustainable economy, we compared the wording, images, and visions of both investigations to determine common features and connecting points.

\section{Results: Stories that (Are Supposed To) Change the World: Linking Narratives of a Sustainable Economy to Research}

\subsection{Narratives in Society—Summary of the Literature Review}

To get an overview of what the current dominant narratives of the sustainable economy in society are, we conducted a literature review. The starting point for the analysis was deciding to adopt the BMBF's definition of the sustainable economy. BMBF, as the research funder, based their programme on this definition. According to this definition, a sustainable economy is an economy that integrates economic competitiveness, environmental protection, social inclusion, and justice. It aims at achieving a low-carbon, resource efficient, and socially inclusive economy, in which income and employment result from investments in sustainability innovations [22]. Building on this definition we analyzed current academic literature and policy documents from national and international political actors and NGOs to get an overview on the different ways of its substantiation.

We found in the literature review from 2016 [12], BMBF's definition can be interpreted in different ways. For the purpose of this paper, it seems appropriate to use rather broad terms, that belong to the same discourse family and which cover a variety of sub-discourses and notions. From this perspective, there are two main societal narratives of the sustainable economy, which point out distinct underlying problem structures and emerging pathways for a sustainability transformation [12]:

1. Green economy narratives: In green economy narratives, the state is often regarded as the central actor, who can foster a sustainable economy by removing environmentally harmful subsidies, incentivizing sustainable innovation etc. Building a sustainable economy within the current economic system seems possible, and proponents generally do not fundamentally question principles such as economic growth being the main factor for prosperity and well-being.

2. Post-growth narratives: from a post-growth perspective, a more fundamental change of the current economic system seems necessary and a fundamental change of values in society is necessary to achieve a sustainable economy. In this view, the current economic relations within national and international economies are questioned and proponents argue in favour of abolishing the goal of achieving economic growth as the main measure of prosperity. In this view, consumers or society are the main drivers of change.

We can find many different tendencies and concepts within these two broader categories of narratives for the sustainable economy, which have been analyzed more in depth in the literature 
review. A number of other studies reached similar conclusions: that there is no single discourse on sustainability or the sustainable economy [24-27].

If we take a closer look at these two main trends in narratives for the sustainable economy, it is possible to extract the main elements of narratives to find differences and commonalities.

\subsubsection{Narratives in Society: Defining the Problem}

Most strands of current discourse on the sustainable economy share the same starting point. For decades scholars have argued that our current model of economic activity is not sustainable, as we are not able to stay within planetary boundaries if we continue without changing the economic system. It would be necessary to consider external effects and to foster and support the development of environmentally friendly innovations, such as new technologies, different consumption patterns, new forms of governance, etc. Hence, more knowledge is needed to develop, test, and scale sustainability innovations $[18,19,28-31]$.

However, the root cause is defined differently within the two main discourses described above. While proponents of the green economy discourse agree that a transformation within the current economic system is possible, this view is challenged and fundamentally criticized in post-growth discourses. In this view, technological and social innovations that achieve higher levels of efficiency and aim at structural economic change are not sufficient. In this view, the current economic system's focus on growth will lead to an over-compensation of the sustainability effects of innovations and rebound effects will lead to even more environmental and social damage. Therefore, the current design and understanding of capitalism and the focus on economic growth as the most important indicator for societal well-being is the main cause of non-sustainable economies [20,21].

However, within the green economy there are also diverging views on the weighing of trade-offs between ecologic sustainability, social inclusion and economic prosperity. Moreover, there is no consensus on whether innovations for increased efficiency can be sufficient for staying within the planetary boundaries. There is no agreement regarding the possibility of preventing rebound effects or if the efficiency potentials are sufficient to achieve a sustainable economy in the long run [32,33].

This shows that the two main discourses have completely different understandings and interpretations of the reasons and root causes which hinder the development of a sustainable economy even though there are some connecting points and similar open questions.

\subsubsection{Narratives in Society: Pathways Towards a Sustainable Economy}

Just as the two discourses describe the reasons for non-sustainability in our current economic system differently, the pathways towards more sustainability also fundamentally differ.

Proponents of green economy narratives argue that a transformation towards a sustainable economy emerges from the interplay between markets, innovations, and the political and legal context in which they are operating [34-36]. Most often, political actors are regarded as the main leverage to initiate and guide transformation processes. Instruments are, for example, regulatory and structural policies such as emission trading, cutting environmentally harmful subsidies, or ecology-oriented tax reforms. However, the different strands of this discourse disagree on the question of if, or to what extent, innovation policies should be supply-oriented (e.g. regulations for businesses on product/ process design) or demand-oriented (e.g. strengthening sustainable consumption patterns) [20].

However, critiques argue that the state has only limited steering capacities (Smith et al. 2005). Hence, post-growth discourses argue that a cultural change is needed to achieve a sustainable economy. From this perspective, societal pioneers take up innovations that are subsequently taken up by broader groups in society $[37,38]$. An important aspect of this cultural change is the redistribution of wealth in society to achieve a more just society [31,39,40]. Following this argumentation, more and more proponents demand that de-growth strategies should be developed and propagated more actively [41-43]. 
Non-sustainability and injustice are also addressed in the context of globalisation. Authors argue that non-sustainability can be traced to the structural crises that result from the current globalised capitalism. This strand, therefore, points to regionalisation strategies for achieving a sustainable economy [44-46].

Depending on the underlying causal model for explaining the current non-sustainable economic patterns, the pathways to a sustainable economy are described differently and point out different actors and governance options [28]. While green economy discourses concentrate on the state at the national level, as well as on businesses and consumers, post-growth discourses put more emphasis on consumers, who are able to initiate a transformation towards a sustainable economy through a cultural change from the bottom up.

\subsubsection{Narratives in Society: Visions for the Future}

Following the two very different problem definitions and the proposed solutions for change, we also find two different understandings of what a future sustainable economy should look like. In both meta-discourses there is agreement that the goal is to stay within the limits of the planetary boundaries.

However, in green economy discourses we observe that, first and foremost, a structural and technological change is required. A future sustainable economy may still be oriented towards economic growth, but innovations in all areas of society lead to more sustainable production and consumption patterns.

In post-growth discourses, we find more radical visions for the future. These entail the departure from economic growth as the guiding principle of our economies. A just distribution of wealth is put at the core to achieve well-being and sustainable consumption patterns prevail. In this view, a cultural shift has taken place, replacing the current values of owning more, bigger, and newer things with a culture of sufficiency. In many cases, this also involves a return to more regionalized markets instead of globalized corporations dominating the economy.

\subsection{Narratives in Research Projects-Workshop Findings}

In the following section, we have summarized the findings from the exercises based on the strategy map [23], which helped to extract the implicitly used elements of the narratives of the participating research projects.

\subsubsection{Elements of Narratives for a Sustainable Economy: The Problem Definition}

In the description of the status quo, the participants focused on the framework conditions for innovation, but also acknowledged that there is no shared vision for a sustainable economy. In sum, these preconditions lead to sustainability deficits of excessive resource use and increasing inequalities. In detail, the participants identified the following problems:

The current economic system is unsustainable in environmental and social terms. Growing demand and large corporations are depleting natural resources, emissions leading to climate change are rising and biodiversity is threatened because our economic patterns are destroying natural habitats. Labour conditions are geared towards maximizing profits, not towards well-being or enabling a good life for everyone. This holds true for the conditions in the global south, but also in western countries. Precarious employment and ensuring family-friendly work environments are problematic in many sectors, for example.

Despite the need for establishing more sustainable production and consumption patterns, changes are hard to introduce for the following reasons:

1. There are no agreed criteria and methods for measuring and evaluating sustainability. There are attempts to develop criteria and indicators for measuring sustainability. However, as there is no shared vision for a sustainable economy, a clear indication of what is sustainable is hard to achieve and, 
therefore, is hard to communicate. For example, proponents of a green economy may have in mind different solutions than proponents of post-growth ideas.

2. Societal and political support for sustainability innovations is insufficient. Even though changes in technology are continuing to rapidly change our lives, these innovations are not inducing change towards sustainability. Currently, there are a lack of incentives to steer the innovation process in this direction. Market success is still the most important criteria. Financial incentives for developing and using sustainable technologies and plans for fostering the sustainability transformation, including strategies for exnovation, are insufficient. Hence, there are a lack of incentives regarding sustainable innovations.

3. Behavioural change of businesses, consumers, and policy makers does not happen rapidly enough. This slow change can be attributed to several factors. Firstly, international supply-chains are not transparent, therefore it is often difficult for consumers to opt for more sustainable products. It is often hard for companies themselves to track all steps of the supply-chain. Secondly, more sustainable options are not available in every case, (e.g. rare earth) and more knowledge on alternative materials is needed. Thirdly, consumers are often unaware that they have an influence by making conscious consumption decisions. Nevertheless, even when more sustainable solutions are available and consumers are aware of them, they often (unconsciously) choose non-sustainable behaviour. Prices are usually higher for sustainable products; they are often harder to come by and values are currently not geared towards sustainable consumption. Rather, consumption is prestigious. People still prefer owning over, for example, sharing.

\subsubsection{Elements of Narratives for a Sustainable Economy: Pathways for Change}

In a second step, the participants were asked to describe pathways to overcome these obstacles. Again, a variety of different possible paths were mentioned:

Firstly, it is vital to promote cooperation to exchange different views on the sustainable economy and to achieve a common understanding about sustainability goals, the innovations needed for achieving them, as well as the specific design of said innovations. Networking strategies and platforms should be developed and expanded and new formats such as living labs should be used more extensively. Creating common goods through sharing or peer production can increase awareness for shared responsibilities.

Secondly, the social dimension of sustainable development should be strengthened to put more emphasis on issues like human rights and labour rights, or equal access to resources. This also includes reducing costs for sustainability transformations (e.g. energy transformation). This would lower the burden for people with deprived backgrounds, and help to create a shared vision for the sustainable economy.

Thirdly, developing sustainability innovations should be promoted more extensively. This requires both changes regarding the innovation process as well as changed framework conditions in markets. The latter aspect requires creating competitive advantages, new forms of corporate governance and supply-chain-management. In terms of organizing the innovation process, the establishment of more participation-oriented processes is needed.

Fourthly, consumer awareness for developing more sustainable behavioural patterns needs to be raised. This includes awareness of options for drastically reducing disposal rates, resource use and emissions, but also strengthening sustainability-oriented developments of the "using instead of owning principle". This can be achieved through sustainability-oriented education and vocational trainings, for example.

\subsubsection{Elements of Narratives for a Sustainable Economy: Visions for the Future}

While the problem definition and the pathways enabled a collection of different aspects, regardless of their relations and specific design, it proved to be more challenging to create a joint vision for the sustainable economy. However, the participants shared some elements of the vision:

In a sustainable economy, solidarity is the leitmotif for economic activities. Economic success is measured against agreed sustainability standards going beyond market success. Customers can make well-informed decisions if supply-chains, labour conditions and environmental impacts are 
transparent and open to scrutiny. The economy is based on an open, participatory innovation culture. Collaborative production methods create common goods and redefine social relations of exchange, based on generalized reciprocity. A well-established infrastructure for open knowledge creation and sharing is accessible for businesses, consumers and decision-makers. Awareness for sustainability is high, sustainable economic decisions are easily made and worthwhile for all members of society.

However, their interpretation and ultimate consequences for the structure of a sustainable economy differed. We will therefore present two visions, which eventually lead to two distinct narratives for the sustainable economy.

- Vision 1: "Small is Beautiful"—Reconfiguring our economic system.

In this vision, the structure of the economy is organized around small or medium-sized, local enterprises, which use innovative, transformative business models. These are mostly decoupled from international value chains and independent from global corporations. Instead, local businesses focus on keeping supply-chains local, using alternative resources and production methods, which will eventually lead to a replacement of international supply-chains. Global corporations become obsolete and will be replaced completely by regional businesses. In this way, production becomes more transparent and environmental standards and labour rights can be more easily checked. Do-it-yourself approaches (e.g. repair-cafes, open workshops, urban gardening) and commons-based peer production of open source knowledge are widely used and sustainable sharing models and up-cycling techniques are well established, so that consumption is dramatically reduced. This leads to a significant drop in resource use and emissions. Innovation processes are organized in participatory ways and it is ensured that sustainability values are incorporated.

In this sustainable economy, a fundamental value shift has taken place. Economic growth is no longer the prevailing indicator for success and well-being; consumers no longer consider owning goods such as the latest fashion items or the newest technology as a status symbol; producers no longer invest in excluding others from using valuable knowledge. Instead, community-oriented values prevail, putting well-being and a good life at the heart of society, which includes quality of life, social cohesion, participation, etc. At least implicitly, the technologies are rather low-tech. The likely decline of variety in products and increasing prices appears to be acceptable or necessary against the benefits of sustainability.

- Vision 2: "Transparent and Manageable"-Adapting our economic system.

In this vision, the economy is building on more sustainable production and consumption patterns. This is achieved by increasing transparency of international supply-chains and increasing standards regarding the environmental and social impact of products. Sustainability innovations are incentivized, which also leads to different innovation processes, which now incorporate societal values from early on. Sustainable solutions are no longer more expensive, rather they are competitive in markets. Therefore, it is easier for consumers to opt for these products. Companies have a strong incentive to look for alternative materials (e.g. replacing rare earths) or more efficient production processes. This change in focus results in a change of the overarching economic goals. Producing (and selling) more goods, increasing the profit margin and ultimately growing in terms of revenue is no longer the main goal. Economies of scale become less important. Instead, network effects resulting from a higher number of users of sustainable solutions gain relevance. Localized or regionalized small-scale technologies are possible. However, unlike technologies in the first vision, they are embedded in the wider economy and utilize economy-wide infrastructures. The positive environmental and social effects resulting from a bigger consumer group of sustainable products and services prevail. This change goes hand in hand with a change in consumer preferences. Consumers are more aware of sustainability issues.

Also, in this view, a change in the value system is taking place, although it is not as fundamental as in the narrative "Small is Beautiful". Sustainability becomes a more prominent decision factor-leading to less consumption. However, current economic principles are still part of evaluating well-being and success. Values like social cohesion, and environmental friendliness, etc. complement current indicators. 


\section{Discussion}

The analysis of research projects on innovation for a sustainable economy revealed some insights regarding the underlying narratives: Firstly, most often, the workshop participants refer to visions for the sustainable economy rather implicitly in their research. The storylines described above have been developed to explicate the ideas, visions, and reasoning for the sustainable economy that have been used implicitly. Secondly, we found two different descriptions of the sustainable economy in this sample of projects. Despite some common viewpoints and corresponding elements of the vision for the future, it was not possible to agree on a joint vision of what a sustainable economy should look like. This was to be expected, as in the literature review [12] we already established that there is no commonly shared understanding of what the sustainable economy is in society either. We can therefore conclude that the results of the projects are possibly targeted at different groups of society or-if not intentionally targeted at specific groups-at least appear to be more compatible with certain groups and are therefore more likely to be adopted in these particular contexts. This leads us to our research question: How the storylines we detected in our analysis link to current societal narratives.

Usually, discourse analysis takes an ex-post perspective: It explains why a narrative has been influential in the past. However, the storylines brought to light during the strategy mapping exercise are not narratives that are being used in societal discussions (yet). However, they tend to use vocabulary and describe images that are used in societal narratives or which are at least compatible with them. Hence, from an ex-ante perspective it is only possible to analyze two main aspects of the vision:

- The compatibility of visions, by referring to the vocabulary and images described and their links to other narratives used in societal discourses.

- Their communication potentials including criteria such as understandability, links to current events, and a coherent storyline.

Hence, in the following section, we will analyze the two narratives from these perspectives to determine if the adopted storylines are compatible with narratives of the sustainable economy prevalent in societal discourse, which we identified in the literature review of 2016 [13]. Secondly, we investigate if the way these have been described is suitable for connecting with these discourses. In this way, we can examine whether the research is likely to be utilized in certain societal discourses and may be able to have an increased impact on achieving the goals of a sustainable economy, as is expected from research funders and society as a whole.

\subsection{Compatibility with the Green Economy and Post-Growth Narratives}

Despite starting from a similar problem definition and assumptions regarding the main obstacles for a sustainable economy, the storylines differ profoundly in their vision for the future. Therefore, the links to current societal discourses differ, too:

Prominent ideas in post-growth views on society can be found in both narratives. For example, the call for more regional-oriented economies or the renunciation of the growth-paradigm are both prominent claims in post-growth communities [13,31,39,40,47]. The "Small is Beautiful" vision, in particular, has links to the movements, which are critical to globalization and the principles of capitalism in general [44-46]. This narrative could also be linked to the discourse "buen vivir" [48] as it stresses the holistic approach of viewing nature, the economy, and human society as an entity and putting the well-being of the community at the forefront [49].

While the "Transparent and Manageable" narrative also has some links to post-growth ideas, like the independence of economic growth, it is also linked to the green economy debate, which is currently the most mainstream view on the sustainable economy. Views expressed in this narrative, such as the ideas of pricing environmental externalities, or the reduction and replacement of (critical) resources, increasing efficiency and creating more transparent supply chains, link to ideas expressed in the green economy discourse [13]. 
Even though both visions leave room for interpretation, they accentuate different aspects of a sustainable economy. They are both linked to more than one relevant societal discourse. However, only the storyline "Transparent and Manageable" seems to be compatible with the currently dominant discourse of the green economy. Therefore, the "Transparent and Manageable" vision is likely to be more compatible with a larger number of potential user groups, whereas the "Small is Beautiful" vision could be taken up by a smaller group who is actively involved in post-growth debates. Hence, the results of the projects have different target groups. These should be considered when developing communication strategies and evaluating the impact of a project.

\subsection{Communication Potentials}

The success of a narrative is partly dependent on its links to current dominant societal discourses. As we have seen above, the narrative "Transparent and Manageable" provides links not just to post-growth discussions, but also to the dominant discourse of the green economy, so that project results can more easily be taken up by society.

Another element is communicability. Real-world examples can make the visions more tangible. However, the visions are currently not explicitly used to contextualize research questions or project results. Therefore, both visions described here lack direct references to current and/ or historic events, which would clarify some of the ideas, create higher levels of identification, and provide clarity as to why the proposed changes will lead to a better future. Still, the descriptions of the visions can be seen as a starting point for further improving the communication of the scientific results.

This seems to be more easily possible with the "Small is Beautiful" narrative. When developing the storyline, the participants embedded the vision in romanticized images of how a community-oriented, local economy could have positive effects on personal relationships and surrounding landscapes, making the personal surroundings more livable. This appeal to emotions is often a contributing factor to the success of narratives [50].

In sum, both visions have the potential to be used for contextualizing research. While the "Transparent and Manageable" storyline has versatile links to current dominant discourses, the narrative "Small is Beautiful" offers more filigreed images of the future that appeal to emotions. In this way, both have the potential to be useful in communicating findings to society with the aim of increasing acceptance for innovations for the sustainable economy. However, it may be necessary to make the links to current societal discourse and the contribution of innovations to societal goals more explicit. This would help to put the innovations into context and enable a broader discussion about their contributions to the broader aims of society.

\section{Conclusions}

Most scientists would not consider the construction and dissemination of narratives as their domain of activity. The ambiguity and normative character of narratives conflict with a scientific approach of demonstrating evidence on causalities 'objectively', and developing and applying precise definitions and concepts. Narratives are a subject of research, but rarely the result of scientific inquiry.

However, as it has been previously demonstrated, narratives are key for the uptake of innovation in society, and in particular for innovation for sustainable development. Scientific inquiry and innovation is not independent from societal discourses. Narratives are not only a means of communication and dissemination, but they shape research, while at the same time they change societal discourses.

Against this understanding of the reflexivity of narratives, we carved out and analyzed firstly the narratives of a sample of research projects on a sustainable economy. Specifically, we identified the underlying visions of a sustainable economy. Secondly, we analyzed how these relate to the broader societal discourse on sustainability.

As expected, narratives are not made explicit by researchers and in research reports. The initial attempt to distill the narratives from publications from a set of projects failed. The structured workshop with its method to distill the narratives by inviting the researchers to positioning themselves on a 
strategy map revealed the implicit narratives embodied in the design and communication of research and innovation for a sustainable economy.

These narratives are not identical with the narratives on a sustainable economy in the discourses of the society as a whole. There are links and matches regarding underlying concepts between the narratives of the researchers, and the narratives in the wider societal discourses. The societal discourse is rather antagonistic between those positions that pursue a reformist green economy strategy and others that argue in favour of systemic changes towards a post-growth economy and society. This antagonism is not mirrored in the narratives applied by researchers. In fact, they connect to both narratives that are dominant in the societal discourses in many cases. It was, however, not possible for the researchers to agree on a joint narrative. The competing views of the societal debate were reflected in their views. The question remains whether this still entails the possibility to develop a bridge between both and to overcome the underlying conflicts. On the one hand, the bridging narratives of researchers tend to increase the ambiguity, and thereby involve the risk of losing a meaning for the protagonists of the debate in society. On the other hand, they are potentially compatible with the different views of the various actors.

Whether narratives that are brought forward by researchers are taken up in society or not, is not only a matter of their qualities and content, but also a question of the interests and views of other actors and the processes and their dynamics in society. Although some ingredients of successful narratives are known, there are no recipes for making narratives societally relevant. Narratives cannot be constructed, they can be found and taken up.

This has at least two implications: Firstly, it is meaningful for researchers to reflect on their implicit narratives and to consider their links to other non-scientific discourses. This has been suggested earlier, given the importance of narratives for the uptake by society. Our analysis has shown that narratives are not only constructed as a means for communication and dissemination of results, but are relevant from the initial steps in designing a research or innovation project. The reflection on the entailed narratives from early on would increase the chances for the uptake of research and it enables dialogue with non-scientific actors.

Secondly, from a funders perspective, a plurality of narratives is an asset, as neither researchers nor funding agencies are able to predict or design future discourses. Hence, they are also not able to predict the resonance of innovations and findings in public discourse. Therefore, it is meaningful to open up research funding programs for research that entails different, even competing narratives. Possibly, a competition on narratives could lead to an innovation in itself that contributes not only to the uptake of research, but also contributes to the wider discourses in society.

Author Contributions: Conceptualization, A.-L.G., K.J.; Methodology, A.-L.G., K.J., D.Z.; Writing-Original draft preparation, A.-L.G. and K.J.; Writing—Review and editing, M.H.-G., J.P., S.S. (Stefan Schridde), S.S. (Sven Stinner), F.W., D.Z., and F.Z.

Funding: This research was funded by Bundesministerium für Bildung und Forschung, grant number 01UT1501C.

Acknowledgments: We thank Prof. Stefan Seuring for his critical comments and helpful remarks. The publication of this article was funded by Bundesministerium für Bildung und Forschung, grant number 01UT1501C.

Conflicts of Interest: The authors declare no conflict of interest.

\section{References}

1. Wolff, F.; Heyen, D.A.; Brohmann, B.; Grießhammer, R.; Jacob, K.; Graaf, L. Transformative Umweltpolitik: Nachhaltige Entwicklung konsequent fördern und gestalten; BMU: Dessau, Germany, 2018.

2. Macnaghten, P.; Davies, S.R.; Kearnes, M. Understanding Public Responses to Emerging Technologies: A Narrative Approach. J. Environ. Policy Plan. 2015, 21, 504-518. [CrossRef]

3. Becker, M. Das digitale Narrativ: Wer schreibt es und was steht drin; Rainer Hampp Verlag: München, Germany, 2019; ISBN 3957103347.

4. Goffman, E. Frame Analysis: An Essay on the Organization of Experience; Harvard University Press: Cambridge, MA, USA, 1971; ISBN 0674316568. 
5. Snow, D.A.; Benford, R.D. Ideology, Frame Resonance, and Participant Mobilization. In From Structure to Action: Comparing Social Movement Research across Cultures; Klandermans, B., Kriesi, H., Tarrow, S.G., Eds.; JAI Press: Greenwich, UK, 1988; pp. 197-217. ISBN 9780892329557.

6. Benford, R.D.; Snow, D.A. Framing Processes and Social Movements: An Overview and Assessment. Annu. Rev. Sociol. 2000, 26, 611-639. [CrossRef]

7. Gadinger, F.; Jarzebski, S.; Yildiz, T. Politische Narrative. Konturen einer politikwissenschaftlichen Erzähltheorie. In Politische Narrative; Springer: Wiesbaden, Germany, 2014; pp. 3-38.

8. Hajer, M. Doing Discourse Analysis: Coalitions, Practices, Meaning. In Netherlands Geographical Studies; KNAG: Utrecht, The Netherlands, 2006.

9. Espinosa, C.; Pregernig, M.; Fischer, C. Narrative und Diskurse in der Umweltpolitik: Möglichkeiten und Grenzen ihrer strategischen Nutzung Zwischenbericht; Federal Environment Agency: Dessau-Roßlau, Germany, 2017.

10. Wittmayer, J.; Backhaus, J.; Avelino, F.; Pel, B. Narratives of Change: How Social Innovation Initiatives Engage with Their Transformative Ambitions. Futures 2019, 112, 1-12. [CrossRef]

11. Stone, D.A. Causal Stories and the Formation of Policy Agendas. Politics Sci. Q. 1989, 104, 281-300. [CrossRef]

12. Viehöver, W. Diskurse als Narrationen. In Handbuch Sozialwissenschaftliche Diskursanalyse; VS Verlag für Sozialwissenschaften: Wiesbaden, Germany, 2001; pp. 177-206.

13. Guske, A.-L.; Jacob, K.; Gotsch, M.; Walz, R. Umfelder Nachhaltigen Wirtschaftens. Available online: https://nachhaltigeswirtschaften-soef.de/sites/default/files/NaWiKo\%20Umfeldanalyse.pdf (accessed on 21 October 2019).

14. Godin, B. The Making of Science, Technology and Innovation Policy: Conceptual Frameworks as Narratives, 1945-2005; Institut National de la Recherche Scientifique: Quebec City, QC, Canada, 2009.

15. Downs, J.S. Prescriptive scientific narratives for communicating usable science. Proc. Natl. Acad. Sci. USA 2014, 111, 13627-13633. [CrossRef]

16. Dahlstrom, M.F. The role of causality in information acceptance in narratives: An example from science communication. Commun. Res. 2010, 37, 857-875. [CrossRef]

17. Nisbet, M.C.; Mooney, C. Science and society: Framing science. Science 2007, 316, 56. [CrossRef]

18. Rockström, J.; Steffen, W.; Noone, K.; Persson, Å.; Chapin, F.S.; Lambin, E.; Lenton, T.M.; Scheffer, M.; Folke, C.; Schellnhuber, H.; et al. Planetary Boundaries: Exploring the Safe Operating Space for Humanity. Ecol. Soc. 2009, 14, 1-35.

19. OECD. Towards Green Growth A Summary for Policy Makers; OECD: Paris, France, 2011.

20. Jacob, K.; Bär, H.; Graaf, L. Metaanalyse von Visionen einer nachhaltigen Gesellschaft, Teilbericht 2 des Projektes Nachhaltiges Deutschland 2030 bis 2050_Wie wollen wir in Zukunft leben; Bundesministeriums für Umwelt: Berlin, Germany, 2015.

21. Jacob, K.; Graaf, L.; Bär, H. Greening des gesellschaftlichen Wandels. Ökologisches Wirtsch. Fachz. 2015, 30, 30. [CrossRef]

22. Bundesministerium für Bildung und Forschung BMBF-Fördermaßnahme "Nachhaltiges Wirtschaften" im Rahmen der Sozial-ökologischen Forschung Hintergrund und Förderziele; Springer: Wiesbaden, Germany, 2014.

23. Zahrnt, D.; Zahrnt, A. Sufficiency Politics Map-Blog Postwachstum. Available online: https://www. postwachstum.de/sufficiency-politics (accessed on 24 September 2019).

24. Stevenson, H. Contemporary Discourses of Green Political Economy: A Q Method Analysis. J. Environ. Policy Plan. 2019, 21, 533-548. [CrossRef]

25. Feindt, P.H.; Oels, A. Does discourse matter? Discourse analysis in environmental policy making. J. Environ. Policy Plan. 2005, 7, 161-173. [CrossRef]

26. McManus, P. Contested terrains: Politics, stories and discourses of sustainability. Environ. Politics 1996, 5, 48-73. [CrossRef]

27. Hajer, M.; Versteeg, W. A decade of discourse analysis of environmental politics: Achievements, challenges, perspectives. J. Environ. Policy Plan. 2005, 7, 175-184. [CrossRef]

28. Jacob, K.; Guske, A.-L.; Antoni-Komar, I.; Funcke, S.; Gruchmann, T.; Kny, J.; Naber, E.; Ruppert-Winkel, C.; Sauer, P.C.; Stumpf, K.H.; et al. Governance for the sustainable economy: Institutional innovation from the bottom up? GAIA 2018, 28, 204-209. [CrossRef]

29. Max-Neef, M. Economic growth and quality of life: A threshold hypothesis. Ecol. Econ. 1995, 15, 115-118. [CrossRef] 
30. Inglehart, R. The diminishing utility of economic growth: From maximizing security toward maximizing subjective well-being. Crit. Rev. 1996, 10, 509-531. [CrossRef]

31. Jackson, T. Prosperity without Growth: Economics for a Finite Planet; Earthscan: London, UK, 2009; ISBN 1844078949.

32. Günther, E. Ökologieorientiertes Management Um-(weltorientiert) Denken in der BWL; mit. 104 Tabellen; UTB: Stuttgart, Germany, 2008; ISBN 9783825283834.

33. Unmüßig, B. Available online: http://www.fortschrittsforum.de/debattieren/geld-glueck/artikel/article/wiegruene-oekonomie-ein-streitthema-wurde.html (accessed on 21 October 2019).

34. Rifkin, J. The Third Industrial Revolution: How Lateral Power is Transforming Energy, the Economy, and the World; Palgrave Macmillan: London, UK, 2013; ISBN 0230341977.

35. Jänicke, M. “Green growth": From a growing eco-industry to economic sustainability. Energy Policy 2012, 48, 13-21. [CrossRef]

36. Jänicke, M.; Jacob, K. A Third Industrial Revolution. In Long-Term Governance for Social-Ecological Change; CRC Press: Boca Raton, FL, USA, 2013; ISBN 9780203556160.

37. Sommer, B.; Welzer, H. Transformation Design: A Social-Ecological Perspective. In Transformation Design: Perspectives on a New Design Attitude; Birkhäuser Verlag: Basel, Switzerland, 2015; ISBN 9783035606539.

38. Sommer, B. Was ist Transformationsdesign? Zu den Möglichkeiten und Grenzen der Gestaltung sozialen Wandels unter normativen Leitbildern In schwerer Sprache. In Inklusiver Arbeitsmarkt; Tectum: Baden-Baden, Germany, 2018.

39. Seidl, I. Postwachstumsgesellschaft: Neue Konzepte fur die Zukunft; Metropolis: Marburg, Germany, 2010; ISBN 3895188115.

40. Leggewie, C.; Welzer, H. Das Ende der Welt, wie wir sie kannten: Klima, Zukunft und die Chancen der Demokratie; Fischer-Taschenbuch-Verl: Frankfurt am Main, Germany, 2011; ISBN 9783596185184.

41. Latouche, S. Le Monde diplomatique. In The International Encyclopedia of Communication; Blackwell Pub.: Malden, MA, USA, 2004.

42. Schneider, F.; Kallis, G.; Martinez-Alier, J. Crisis or opportunity? Economic degrowth for social equity and ecological sustainability. Introduction to this special issue. J. Clean. Prod. 2010, 18, 511-518. [CrossRef]

43. Martínez-Alier, J.; Pascual, U.; Vivien, F.D.; Zaccai, E. Sustainable de-growth: Mapping the context, criticisms and future prospects of an emergent paradigm. Ecol. Econ. 2010, 69, 1741-1747. [CrossRef]

44. Brunnengräber, A. Eine weltbürgerbewegung ohne realitätsbezug: Zum WBGU-sondergutachten klimaschutz als weltbürgerbewegung. GAIA 2014, 23, 306-308. [CrossRef]

45. Miegel, M.; Brand, U. Kritik am Wachstumsparadigma. Zwei Positionen. Aus Politik und Zeitgeschichte 2012, 62, 3-14.

46. Altvater, E. Mit Green New Deal aus dem Wachstumsdilemma. Available online: https://widerspruch.ch/ sites/widerspruch.ch/files/pdf/wsp60_altvater.pdf (accessed on 29 October 2019).

47. Muraca, B. Gut leben Eine Gesellschaft jenseits des Wachstums; Wagenbach, K., Ed.; Klaus Wagenbach Verlag: Berlin, Germany, 2014.

48. Acosta, A. Buen Vivir: Vom Recht Auf Ein Gutes Leben; [das Wissen Der Anden Für Eine Welt Jenseits Des Wachstums; Oekom: München, Germany, 2015; ISBN 978-3865817051.

49. Fatheuer, T. Buen Vivir. Eine kurze Einführung in Lateinamerikas neue Konzepte zum guten Leben und zu den Rechten der Natur; Heinrich-Böll-Stiftung: Berlin, Germany, 2011.

50. Arnold, M. Erzählen. Die ethisch-politische Funktion narrativer Diskurse. In Erzählungen im Öffentlichen; VS Verlag für Sozialwissenschaften: Wiesbaden, Germany, 2012; pp. 17-63.

(C) 2019 by the authors. Licensee MDPI, Basel, Switzerland. This article is an open access article distributed under the terms and conditions of the Creative Commons Attribution (CC BY) license (http://creativecommons.org/licenses/by/4.0/). 